\title{
Institutional Price Pressure: Evidence From NASDAQ - NYSE Listings
}

Jimmy D. Senteza (Email: Jimmy.Senteza@drake.edu), Drake University

\begin{abstract}
The abnormal return behavior of firms that change their listing from the NASDAQ to the NYSE is found to be in the main a function of institutional ownership changes rather than changes in outstanding shareholder ownership as suggested in previous work. Institutional price pressure rather than changes in overall shareholder ownership is found to explain the pre-and the postlisting abnormal returns of sample firms.
\end{abstract}

\section{Introduction}

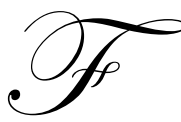

irms listing on the NYSE from the NASDAQ exhibit peculiar return behavior around their listing. They earn abnormally high returns before the change in listing and abnormally low returns afterwards. One rationale used to explain the stock return behavior is based on the investor recognition hypothesis of Merton (1987). Proponents argue that an increase in investor recognition or 'awareness', usually measured by the overall number of shareholders of a firm, explains the abnormal return behavior exhibited by the listing firms around listing changes. However, the investor recognition hypothesis is not the only explanation for why the abnormal return pattern reverses in the post-listing period. In distinguishing institutional ownership changes from overall shareholder changes in listing firms, we find that this classic abnormal return behavior around listing is primarily influenced by institutional ownership changes causing price pressure.

According to several recent studies that investigate the abnormal return behavior of both international cross-listing securities (Foerster and Karolyi (1999), and Miller (1999)) and domestic listing changes (Amihud, Mendelson, and Uno (1999), Kadlec and McConnell (1994)), sample securities garner positive abnormal returns prior to listing on the new exchange. The studies also find that after the firms have listed on the new trading location, the abnormal return pattern is reversed and is typically negative up to thirty-six months after the firms have listed. Their findings are offered as evidence for the investor recognition hypothesis of Merton (1987). Evidence for this support is based on increases in the number of shareholders between the pre- and post-listing windows as a proxy for "firms' investor base". Baker, Powell, and Weaver (1999) use two alternate proxies and control variables to test if visibility (recognition) increases when firms list on the NYSE from abroad - the number of analysts following the firm and the number of institutional shareholders. They find that visibility measured by the two proxies increases significantly between the pre- and post-listing periods. Baker, Nofsinger, and Weaver (2002) use the number of analysts following the stock, and the number of citations in leading financial newspapers to proxy the magnitude of investor recognition and find increased recognition as well.

However, the characteristic abnormal return behavior of listing firms, where positive pre-listing abnormal returns reverse to negative abnormal returns after firms list as reported in extant work seems to suggest price pressure effects caused by pre-listing buying and post-listing selling pressures. Effectively, the impact of listing on firm value may be transient, bringing into question how well this pattern is supported by the investor recognition hypothesis of Merton (1987). Moreover, in his words, Merton (1987) asserts that

Ceteris paribus ... an increase in the relative size of the firms' investor base will reduce the firm's cost of capital and increase the market value of the firm. 
In essence, the abnormal return reversal evident after firms have listed on the new exchange is some evidence of the investor recognition hypothesis. This study, however, reveals that whereas increases occur in the overall size of ownership and capitalization of listing firms, share value does decline on average, but also that the negative post-listing abnormal returns of subject firms may be a result of institutional ownership declines. We offer an alternative explanation for this return pattern. Specifically, we argue that the observed abnormal return patterns surrounding these events are likely price pressure effects caused by institutional investors trading.

\section{Motivation and Literature Review}

According to Elliot and Warr (2003), price effects associated with similar changes in firms' market characteristics can be either permanent (due to increased stock demand or better liquidity) or transient hence reverting to zero. The observations from the studies cited above suggest that the price behavior of securities around the change of listing location is clearly non-permanent consistent with the price pressure hypothesis. According to Hudson, Jensen, and Pugh (1993), the behavior is explained by the price pressure hypothesis as follows: The observed reversal in returns between the pre- and post listing periods seems to suggest that the effect of firm revaluation is mostly temporary, consistent with the price pressure hypothesis. Effectively, the hypothesis predicts that buying pressure created by investors before the firms list generates positive abnormal returns. After the firms list, however, the buying pressure subsides and selling pressure generates the observed negative post-listing abnormal returns (similar to Liang (1999)). The hypothesis assumes that temporarily, there is a non-perfectly elastic demand for the firms' shares (e.g. Asquith and Mullins (1986)).

Elliot and Warr (2003, pp. 26, Table II) show that NASDAQ stocks particularly, experience temporary shocks around the listing change. According to them, unlike NYSE listed additions, NASDAQ listed additions to the S\&P 500 exhibit significant positive abnormal returns on the listing day and significant negative abnormal returns the day after listing. Listing day abnormal returns are reported as 3.41\% for NASDAQ additions and $0.75 \%$ for NYSE additions, and day after listing abnormal returns are $-1.15 \%$ and $-0.61 \%$ respectively. Evidently NASDAQ listed firms exhibit relatively more price pressure around the changes in firms' market characteristics.

There are several reasons why we argue that the price-pressure originates mainly from institutional investors. First, based on the information hypothesis, institutional investors are purported to have more superior knowledge about firms than other investors. Several pieces of empirical evidence suggest that institutional investors are generally more sophisticated than individual investors and their ability to monitor and procure information about the firms they buy, is different from that of individual investors. For instance, Cohen, Gompers, and Vuolteenaho (2002) in a recent study examine how institutional and individual investors react to new information about a firm's cash flow. They find that a 25 percent positive shock in cash-flow news ${ }^{1}$ results in institutional investors buying about 2 percent of the shares outstanding from individual investors. Institutions also sell 5 percent of the shares outstanding to individual investors if the stock price increases 25 percent without any concurrent cash flow news. Their assessment is that individual investors are slow in responding to cash-flow news and that institutional investors may be better informed in this situation.

A second reason why the price-pressure effect is likely to originate from institutional investors comes from corporate governance studies that describe incentives that compel institutional investors to keep an unyielding eye on their holdings. Gillan and Starks (2000) suggest that institutional investors have a strong incentive to monitor since they cannot always simply rid themselves of under-performing stock. Further, Karpoff, Malatesta, and Walking (1996) suggest that since institutional owners have sizable stakes in the firms they own, managers of these firms will be more willing to comply with their demands.

Further evidence of the influence of institutional investors comes from a vast body of literature providing empirical evidence about the relationship between institutional trading behavior and security returns. Pruitt and Wei (1989) demonstrate a positive correlation between changes in institutional holdings and firm abnormal returns following the listing or de-listing announcement of firms. Grinblatt, Titman and Wermers (1995), Nofsinger and Sias (1999), Wermers (1999), and others show that security returns are contemporaneously correlated with institutional trading. Other studies show support for the hypothesis that institutional investors are short-term positive 
feedback traders. Nofsinger and Sias (1999), Wermers (1999), and Gompers and Metric (2001) find higher (lower) near-term expected returns for stock that experienced increased institutional buying (selling). Moreover, institutional investors held over 45 percent of stocks in the US by the end of the third quarter of 2001. Their trading volume alone has been documented to account for over 70 percent on the trading on the NYSE (Schwartz and Shapiro (1992), Lakonishok, Shleifer, and Vishny (1992), Brown and Brooke (1993)).

The rest of the paper is organized as follows: the data and empirical methodology used to obtain abnormal returns are described in section 3, the results of the two approaches we use in the investigations are discussed in sections 4, and 5. We conclude in section 6 and offer suggestions for future research in section 7.

\section{Data and Methodology}

Data for this study come from several sources. Monthly returns (1983-1997) of listing firms, returns on a value-weighted monthly index of the S\&P 500 universe, and the return on the 30-day Treasury bill are obtained from the Center for Research in Security Prices (CRSP). Data on the number of shareholders over the sample period are obtained from Standard and Poors' Research Insight. Quarterly institutional ownership data are derived from CDA Spectrum's database of 13(f) institutional investors. All institutional investors with holdings over \$100 million in equities are required to file 13(f) forms quarterly in which they disclose their equity holdings to the Securities and Exchange Commission (SEC). The information is filed in accordance with the institutional disclosure program mandated by section 13(f) ${ }^{2}$ of the Securities and Exchange Act of 1934 ("1934 Act").

From the CRSP monthly firm data we find 681 change of listings from the NASDAQ to the NYSE. As reported in Table 1, most changes in listing occurred towards the later part of the study period but listing changes are fairly evenly spread out over the fifteen year period. The listing changes were inspected to verify whether there was a one-on-one correspondence between each listing and firm. Also, sample firms had to have at least twelve months and thirty-six months worth of pre- and post-listing observations respectively. Thus all listing changes before 1984 and those after 1994 were eliminated from our sample. All firms meeting these requirements were used in the analysis whether or not they eventually de-listed from the NYSE. The final sample consists of 417 listing changes (416 firms). Rhodes Inc. New listed two times on the NYSE from the NASDAQ during the sample period and may have de-listed from the NYSE in the interim after falling short of the NYSE listing requirements.

681 NASDAQ to NYSE listing changes are found during the sample period 1983-1997. The year-by-year numbers of listing changes are provided in the table below. Data are obtained from CRSP.

Similar to Foerster and Karolyi (1999) below capturing both the pre- and post-listing Standard and Poors' 500 value-weighted market index as a market proxy. For each firm j, abnormal returns are obtained via a dummy variable regression of the firm's monthly excess returns $R_{j}$ as follows: we estimate the Asset Pricing Model (APM) abnormal returns periods relative to the

\section{Table 1: Listing Changes By Year}

\begin{tabular}{lc}
\hline Year & NASDAQ to NYSE \\
\hline 1983 & 24 \\
1984 & 24 \\
1985 & 23 \\
1986 & 31 \\
1987 & 44 \\
1988 & 53 \\
1989 & 36 \\
1990 & 37 \\
1991 & 40 \\
1992 & 47 \\
1993 & 43 \\
1994 & 39 \\
1995 & 62 \\
1996 & 85 \\
1997 & 93 \\
\hline Total & $\mathbf{6 8 1}$ \\
\hline
\end{tabular}

$\mathrm{R}_{\mathrm{j}}=\alpha_{j}^{P R E} D^{P R E}+\beta_{j}^{P R E} R^{m} D^{P R E}+\alpha_{j}^{P O S T} D^{P O S T}+\beta_{j}^{P O S T} R^{m} D^{P O S T}+\varepsilon_{j}$.

where, $\alpha_{j}^{\text {PRE }}$ and $\alpha_{j}^{\text {POST }}$ the pre- and post-listing regression intercepts are our estimates of the pre- and post-listing abnormal returns for firm $\mathrm{j}$ respectively. $\beta_{\mathrm{j}}^{\mathrm{PRE}}$ and $\beta_{\mathrm{j}}{ }^{\mathrm{PRE}}$ are the pre- and post-listing coefficients on the excess 
monthly return for the CRSP value-weighted portfolio $\mathrm{R}^{\mathrm{m}}, \mathrm{D}^{\mathrm{PRE}}$ is a dummy variable that equals one if sample observations of firm excess returns fall in the pre-listing month and equals zero otherwise, and $\mathrm{D}^{\mathrm{POST}}$ is a dummy variable that equals one if sample observations of firm returns fall in the post-listing month and equals zero otherwise. The parameter estimates derived for each firm from the regression above are pooled cross-sectionally and averages of the pre-listing and post listing abnormal returns are reported in Table 2. We use a twelve-month prelisting window and a thirty six-month post-listing window for each firm.

Consistent with previous findings, our sample firms earn significantly positive abnormal returns twelve months prior to listing on a new market and earn significantly negative abnormal returns thereafter (refer to Table 2). Interestingly, pre-listing negative abnormal returns are significant over the 12 month period but not the 6 month period before the firms change listing. Negative post-listing abnormal returns are evident up to 36 months after a firm has listed on the new exchange i.e. average monthly abnormal returns of approximately -1.2 percent are observed.

Abnormal returns are obtained by running the cross-sectional regression below on each firm's monthly returns over specific periods in the table.
Table 2: Summary Of Abnormal Returns

\begin{tabular}{lcc}
\hline & $\begin{array}{c}\text { Pre-/Post- } \\
\text { Listing period } \\
\text { (months) }\end{array}$ & $\sum_{j=1}^{n} \alpha_{j}{ }^{\text {PRE / POST }} / n$ \\
\hline & -6 to -1 & 0.0027 \\
& $(0.99)$ \\
& -12 to -1 & 0.0666 \\
& 1 to 6 & $(3.78)^{* * *}$ \\
& 1 to 12 & -0.01 \\
& & $(-3.12)^{* * *}$ \\
& 1 to 24 & -0.01148 \\
& 1 to 36 & $-5.66)^{* * *}$ \\
& & -0.0117 \\
& & $-6.92)^{* * *}$ \\
$* * *$ & Significant at 1 percent level & -0.0119 \\
$* *$ & Significant at 5 percent level & $(-7.59)^{* * *}$ \\
$*$ & Significant at 10 percent level & \\
$\beta_{j}^{\text {POST }} R^{m} D_{j}^{\text {POST }}+\varepsilon_{j}$ &
\end{tabular}

where $\beta_{\mathrm{j}}$ is firm j's coefficient on the market excess returns, $\mathrm{R}^{\mathrm{m}}$ is the excess monthly return on the CRSP valueweighted portfolio in month $t, D_{j}{ }^{P R E}$ is a dummy variable that equals one when firm $j$ 's return observation falls in the pre-listing month but equals zero otherwise, and $D_{j}^{\text {POST }}$ is a dummy variable that equals one when firm $j$ 's return observation falls in the post-listing month but equals zero otherwise. Coefficients $\alpha_{j}^{\text {PRE }}$ and $\alpha_{j}^{\text {POST }}$ are averaged as indicated below where $n$ is the number of firms. T-statistics are reported in brackets. Similar to the existing findings abnormal returns to firms increase on average prior to a listing change and decrease thereafter.

CRSP data and the abnormal returns are then merged with the institutional holdings data for further analyses. Average characteristics of the sample of listing are summarized in Table 3 for select event months starting twelve months before listing, and up to thirty-six months after listing. On average the outstanding number of shareholders in listing firms increases by 56 percent from the period one year before to the period one year after the listing event. This increase is likened to a 40 percent average increase in the number of outstanding shares listing firms end up with over the same period. Dharan and Ikenberry (1995) find that it is not uncommon for firms to issue seasoned equity immediately before or after they list on new capital markets. As a matter of fact by the end of the third year after sample firms have listed, outstanding shares have doubled on average, but the average number of outstanding shareholders increases by only 38 percent.

The sample of listing firms at seven randomly selected event months is characterized. The table below provides averages on five variables of this sample for the selected event months. In a way, we characterize an average listing firm based on the list of variables. In total 416 listings in the CRSP merge with the institutional data set (the CDA Spectrum data) over the sample period 1983 - 1997. Below, we report the characteristics of an average listing firm in the institutional ownership-CRSP merged data set during the event month in the top row of each column. 
Table 3: Average Characteristics Of The Listing Change Sample Firms.

\begin{tabular}{|c|c|c|c|c|c|c|c|c|c|}
\hline Event month & PRE $=-12$ & $P R E=-6$ & $\begin{array}{c}\text { EVENT } \\
\text { MONTH }\end{array}$ & POST $=+6$ & POST $=+12$ & POST $=+24$ & POST $=+36$ & $\begin{array}{c}\begin{array}{c}\text { 2-year } \\
\text { change }^{4}\end{array} \\
\text { cheng }\end{array}$ & $\begin{array}{c}\text { 4-year } \\
\text { change }^{5}\end{array}$ \\
\hline $\begin{array}{l}\begin{array}{l}\text { Num.of } \\
\text { shareholders }\end{array} \\
\end{array}$ & 3,730 & 4,131 & 4,731 & 5,693 & 5,820 & 5,952 & 5,157 & 0.560 & 0.383 \\
\hline $\begin{array}{l}\text { Shares } \\
\text { (monthly } \\
\text { in '000s) }\end{array}$ & $15,486.49$ & $16,403.13$ & $17,295.70$ & $19,695.20$ & $21,803.44$ & $25,346.33$ & $31,225.96$ & 0.408 & 1.016 \\
\hline Number of inst. & 24 & 29 & 32 & 36 & 41 & 47 & 56 & 0.708 & 1.333 \\
\hline $\begin{array}{l}\text { Fract. of shares } \\
\text { by inst. }\end{array}$ & 0.199 & 0.231 & 0.246 & 0.260 & 0.279 & 0.307 & 0.345 & 0.402 & 0.734 \\
\hline $\begin{array}{l}\text { Capitalization } \\
\text { ('000) }\end{array}$ & $\$ 365,910.03$ & $\$ 402,088.93$ & $\$ 446,491.47$ & $\$ 495,017.58$ & $\$ 528,633.27$ & $\$ 624,081.87$ & $\$ 685,708.32$ & 0.445 & 0.874 \\
\hline $\begin{array}{l}\text { Average } \\
\text { Share value }^{7}\end{array}$ & $\$ 23.63$ & $\$ 24.51$ & $\$ 25.82$ & $\$ 25.13$ & $\$ 24.25$ & $\$ 24.62$ & $\$ 21.96$ & 0.026 & -0.071 \\
\hline
\end{tabular}

Average firm market capitalization increases by 44.5 percent from a year before to a year after listing and this trend continues reaching an overall increase of 87.4 percent by the end of the third year after sample firms have listed. To put this into perspective, we compute an average share value as described in Table 3. Share value on average increases until the event month and trends downward generally after firms have listed. In other words, firm share values increase on average before listing but decline on average after firms have listed on the NYSE. As a matter of fact, from the period one year before listing to the period three years after sample firms listed, average share value declines by approximately 7.1 percent. Overall, therefore, even though we observe an increase in the outstanding number of shareholders to sample firms, this is not followed by an increase in firm share value. Only increases in overall market capitalization occur and they may be attributable to overall increases in outstanding shares. This assessment shows that the increase in investor recognition occurs as the compound effect of increases in the overall firms' shares and in the outstanding number of shareholders which means overall firm capitalization increases as well. At the share price level, however, price-pressure effects potentially lead to the abnormal returns behavior documented among listing firms and the eventual share price depreciation. Note that the level of institutional ownership, both their number and fraction also increase on average. Later we show that even though institutional ownership grows on average, this increase is associated with an increase in abnormal returns. We show that firms that experience declines in the levels of ownership by institutional investors exhibit erosion in abnormal returns after listing. Next we demonstrate support for the price-pressure hypothesis by examining the relationship between institutional ownership changes and listing firm abnormal returns.

\section{Sophisticated Investors And Investor Recognition}

We perform a cross-sectional regression analysis in which we compare a commonly used measure of investor recognition with a proxy for institutional ownership changes in listing firms (the result of their buying and/or selling the firms' stock). The measure of investor recognition previously used in Kadlec and McConnell (1994) and Foerster and Karolyi (1999) specifically, for a security j, is computed as follows:

$$
\Delta \lambda_{j}(\text { numshar })=\sigma_{\varepsilon j}^{2} \operatorname{SIZE}_{j}\left(1 / \text { numshar }_{t+1}-1 / \text { numshar }_{t-1}\right) .
$$

where $\sigma_{\varepsilon j}{ }^{2}$ is the residual variance for firm $\mathrm{j}$ obtained from our regression equation (1), $S I Z E_{j}$ is the market value of security $j$ at the time of listing, numshar ${ }_{t+1}$ and numshar ${ }_{t-1}$ are number of institutional investors owning security $j$ in periods $\mathrm{t}+1$ and $\mathrm{t}-1$ respectively. For interpretational purposes, note that $\Delta \lambda_{\mathrm{j}}$ (numshar) is a decreasing function of increases in the overall number of shareholders in firm $\mathrm{j}$. The measure of changes in institutional ownership is obtained my merely replacing the number of overall shareholders variable (numinst) by the number of institutional investors variable (numshar) in (2) above. 
Three separate ordinary least squares (OLS) equations (3), (4), and (5) are estimated. Firm abnormal returns are regressed on the two measures obtained from (2) above $-\Delta \lambda_{j}$ (numshar) and $\Delta \lambda_{j}$ (numinst) - as follows:

$\operatorname{AR}_{\mathrm{j}}^{\mathrm{T}}=\gamma+\beta_{1}\left[\Delta \lambda_{\mathrm{j}}(\right.$ numinst $\left.)\right]+\varepsilon_{\mathrm{j}}$

$\operatorname{AR}_{\mathrm{j}}^{\mathrm{T}}=\gamma+\beta_{2}\left[\Delta \lambda_{\mathrm{j}}\right.$ (numshar) $]+\varepsilon_{\mathrm{j}}$

$\mathrm{AR}_{\mathrm{j}}^{\mathrm{T}}=\gamma+\beta_{1}\left[\Delta \lambda_{\mathrm{j}}(\right.$ numinst) $\left.)\right]+\beta_{2}\left[\Delta \lambda_{\mathrm{j}}(\right.$ numshar $\left.)\right]+\varepsilon_{\mathrm{j}}$

where $\mathrm{AR}_{\mathrm{j}}{ }^{\mathrm{T}}$ represent firm j's abnormal returns in the pre-listing $(\mathrm{T}=\mathrm{PRE})$ or in the post-listing $(\mathrm{T}=\mathrm{POST})$ period.

Table 4 summarizes the OLS estimates of the above regressions. We interpret the results from regressions on the pre- and post-listing variables with two caveats. First, as stated earlier, $\Delta \lambda_{j}$ (numinst) and $\Delta \lambda_{j}$ (numshar) are inverse functions of changes in the number of institutional owners and of changes in the number of outstanding shareholders respectively. Second, firms on average garner positive abnormal returns before and negative abnormal returns after listing on the NYSE from the NASDAQ. Therefore, going by the investor recognition hypothesis, we should expect the coefficients on the variables $\Delta \lambda_{\mathrm{j}}$ (numinst) and $\Delta \lambda_{\mathrm{j}}$ (numshar) to be negative in the pre-listing and positive in post-listing regressions (3) - (5). Our findings are quite revealing as described below.

Cross-sectional estimates suggest that the number of institutional investors, unlike the number of outstanding shareholders, is positively associated with pre-listing abnormal returns among listing firms. The twelvemonth pre-listing abnormal return regression estimates suggest a direct and significant relationship between the number of institutional investors and pre-listing abnormal returns but no significant relationship with the overall number of shareholders. Institutional ownership alone explains 16.56 percent of the observed variability in the twelve-month pre-listing abnormal returns. Also, prior to listing, institutional ownership seems to explain observed abnormal returns much better than measures of investor recognition as in the pre-listing results of regression (5). Overall, the pre-listing results are consistent with previous findings.

From Table 4, coefficients on $\Delta \lambda_{j}$ (numshar) are positive and significant in the 36-month post-listing abnormal returns regressions (3) and (5). In contrast, however, coefficients on $\Delta \lambda_{j}$ (numinst) are all negative in the 24- and 36-month post-listing regressions. Significance levels are 95 percent in two of four and 90 percent in one of four coefficients. The negative relationship evident here suggests that the observed negative abnormal returns are associated with declines in ownership by institutional investors who effectively trim their sample firms' holdings after they list on the NYSE. This result seems to challenge inferences made from Table 3 where it is shown that overall institutional ownership does increase after firms list on the NYSE. Thus in the subsequent analysis an attempt is made to characterize sample firms' pre- and post-listing abnormal returns based on the size of changes in institutional ownership levels.

Sample listing firm abnormal returns for periods $\mathrm{t}=-12,12,24$ and 36 months are regressed on the investor recognition proxies. Simple regressions are used to perform the procedure in comparing the proxies. The regressions performed appear below. The null hypothesis being tested in each regression is that the coefficient on each recognition proxy is equal to zero. The results of running heteroskedastically consistent regressions are reported in the subsequent table. Separately, an F-test rejects the null hypothesis the $\beta_{1}=\beta_{2}$ at a 1 percent level.

$\mathrm{AR}_{\mathrm{j}}^{\mathrm{T}}=\gamma+\beta_{1}\left[\Delta \lambda_{\mathrm{j}}\right.$ (numinst) $]+\varepsilon_{\mathrm{j}}$
$\mathrm{AR}_{\mathrm{j}}^{\mathrm{T}}=\gamma+\beta_{2}\left[\Delta \lambda_{\mathrm{j}}\right.$ (numshar) $]+\varepsilon_{\mathrm{j}}$
$\mathrm{AR}_{\mathrm{j}}^{\mathrm{T}}=\gamma+\beta_{1}\left[\Delta \lambda_{\mathrm{j}}\right.$ (numinst) $]+\beta_{2}\left[\Delta \lambda_{\mathrm{j}}(\right.$ numshar $\left.)\right]+\varepsilon_{\mathrm{j}}$

where $\mathrm{AR}_{\mathrm{j}}{ }^{\mathrm{T}}$ represent firm $\mathrm{j}$ 's abnormal returns in the pre-listing $(\mathrm{T}=\mathrm{PRE})$ or in the post-listing $(\mathrm{T}=\mathrm{POST})$ period, $\Delta \lambda_{j}$ (numinst) and $\Delta \lambda_{j}$ (numshar) are the measures of investor recognition proxies over the $\mathrm{AR}_{\mathrm{j}}^{\mathrm{T}}$ measurement period. The former measure uses the overall number of shareholders while the later uses the number of institutional investors. T-statistics are included in brackets. 
Table 4. OLS Results Of Abnormal Returns Regressed On Sample Listing Firms

\begin{tabular}{|c|c|c|c|c|c|c|c|}
\hline & & \multicolumn{3}{|c|}{ Pre-Listing Period Estimates } & \multicolumn{3}{|c|}{ Post Listing Period Estimates } \\
\hline Period & Equation & (3) & (4) & (5) & (3) & (4) & (5) \\
\hline \multirow{4}{*}{12 months } & Intercept & $\begin{array}{l}0.232 \\
(1.51) \\
\end{array}$ & $\begin{array}{c}0.883 \\
(4.34)^{* * *}\end{array}$ & $\begin{array}{c}0.421 \\
(2.15)^{* *}\end{array}$ & $\begin{array}{c}-0.948 \\
(-4.90) * * *\end{array}$ & $\begin{array}{c}-0.646 \\
(-2.77) * * * \\
\end{array}$ & $\begin{array}{c}-0.610 \\
(-2.47)^{* *}\end{array}$ \\
\hline & $\Delta \lambda_{\text {j\# of shareholders }}$ & & $\begin{array}{c}-0.0001 \\
(0.32)\end{array}$ & $\begin{array}{l}-0.000 \\
(-0.16) \\
\end{array}$ & & $\begin{array}{l}-0.001 \\
(-1.19)\end{array}$ & $\begin{array}{l}-0.001 \\
(-1.19) \\
\end{array}$ \\
\hline & $\Delta \lambda_{\text {j\# } \text { of inst. investors }}$ & $\begin{array}{c}-0.004 \\
(-9.94) * * *\end{array}$ & & $\begin{array}{c}-0.004 \\
(-7.94)^{* * *}\end{array}$ & $\begin{array}{l}-0.006 \\
(-0.08)\end{array}$ & & $\begin{array}{l}-0.039 \\
(-0.99)\end{array}$ \\
\hline & Adj. $\mathrm{R}^{2}$ & $16.56 \%$ & $-0.32 \%$ & $18.09 \%$ & $-0.20 \%$ & $0.14 \%$ & $-0.21 \%$ \\
\hline \multirow{4}{*}{24 months } & Intercept & & & & $\begin{array}{c}-0.120 \\
(-7.14)^{* * *}\end{array}$ & $\begin{array}{c}-0.907 \\
(-4.24) * * *\end{array}$ & $\begin{array}{c}-0.969 \\
(4.26)^{* * *}\end{array}$ \\
\hline & $\Delta \lambda_{\text {j\# of shareholders }}$ & & & & & $\begin{array}{l}0.061 \\
(1.29)\end{array}$ & $\begin{array}{l}0.078 \\
(1.51) \\
\end{array}$ \\
\hline & $\Delta \lambda_{\text {j\# } \text { of inst. investors }}$ & & & & $\begin{array}{c}-0.008 \\
(-2.00)^{* *}\end{array}$ & & $\begin{array}{c}-0.001 \\
(-1.68)^{*}\end{array}$ \\
\hline & Adj. $\mathrm{R}^{2}$ & & & & $0.75 \%$ & $0.31 \%$ & $1.21 \%$ \\
\hline \multirow{4}{*}{36 months } & Intercept & & & & $\begin{array}{c}-0.134 \\
(9.20)^{* * *}\end{array}$ & $\begin{array}{c}-0.943 \\
(-5.94) * * *\end{array}$ & $\begin{array}{c}-0.106 \\
(-6.15)^{* * *}\end{array}$ \\
\hline & $\Delta \lambda_{\text {j\# } \text { of shareholders }}$ & & & & & $\begin{array}{c}0.065 \\
(1.73)^{*}\end{array}$ & $\begin{array}{c}0.076 \\
(2.00)^{* *}\end{array}$ \\
\hline & $\Delta \lambda_{\text {j\# } \text { of inst. investors }}$ & & & & $\begin{array}{l}-0.001 \\
(-1.41) \\
\end{array}$ & & $\begin{array}{c}-0.001 \\
(-2.04)^{* *} \\
\end{array}$ \\
\hline & Adj. $\mathrm{R}^{2}$ & & & & $0.30 \%$ & $1.07 \%$ & $2.96 \%$ \\
\hline
\end{tabular}

Thus far, however, the results provide some support for increased "investor awareness" of listing firms defined as an increase in shareholders but it is the shrinkage in institutional ownership that corroborates documented negative post-listing abnormal returns. More importantly, when we combine both the pre- and post-listing findings, we see that institutional investors on average, garner positive pre-listing abnormal returns of the listing stocks but do not hold on long to the stocks after they list on a new exchange. The pattern evident is that increases in institutional ownership (or their buying) of listing firms prior to the listing event leads to an upsurge in abnormal returns. Following the listing on the NYSE, however, the decline in ownership by institutional investors (or their selling of stock in the firms) leads to the observed negative abnormal returns. Thus institutional ownership behavior seems to exert pressure on the prices of sample firms both before and after the firms list. Hence, even though there is an overall increase in 'investor awareness' of listing firm, their abnormal return behavior is effectively a function of institutional ownership changes in the stocks.

To characterize the observed relationship between sample firm abnormal returns and levels of institutional ownership, we use a portfolio formation technique described below.

\section{Abnormal Returns And Institutional Holdings Across Listing Firm Portfolios}

We take all firms in the sample at the beginning of the study period ${ }^{10}$ and stratify them into ten 'initial' portfolios based on the fraction of shares held by institutional investors ${ }^{11}$. Each decile then constitutes firms with similar levels of institutional holdings. We further sort each of the ten institutional-ownership-sorted portfolios based on the change in the fraction of institutional ownership for each firm. The change in the fraction of institutional ownership is measured as the fraction of institutional holdings at the end of the specified period minus the fraction at the beginning of the period. At this point, there are 100 initial ownership-change in institutional holdings stratified portfolios. Finally, we re-aggregate the portfolios by putting together all firms in the same change 
in ownership decile across each of the initial ownership level decile. For instance, firms sorted as having the largest change in institutional holdings in each of the initial fraction of institutional holdings sorted portfolios, are reaggregated into a single portfolio that suffers the largest loss in institutional ownership. We do so for each of the change in institutional holdings deciles and end up with ten 'initial ownership stratified, change in institutional ownership portfolios'. We then derive the average abnormal returns and ownership characteristics of each one of the ten portfolios. The portfolio aggregation ${ }^{12}$ method we use here has some important advantages. First, it allows us to analyze the relationship between changes in institutional holdings and abnormal returns. Second, it is possible to see how institutional ownership, on average, is associated with abnormal return characteristics of sample firms. The results appear in Table 5.

The results suggest that firms experiencing a large loss in institutional ownership tend to earn significantly negative abnormal returns prior to listing. Both the twelve-month and the six-month pre-listing abnormal returns are significantly negative for securities in the decile with the biggest decrease in institutional ownership. Similarly, firms that experience a big gain in institutional holdings tend to earn positive abnormal returns in the pre-listing period. The monthly abnormal returns average approximately 2.25 percent and 2.13 percent for the twelve and sixmonth period before listing respectively for firms in the decile with the biggest gain in institutional ownership.

After the firms list on the exchange, we again observe from Table 5 that those firms with the highest loss in institutional ownership tend to have significantly high negative abnormal returns. However, firms that have the biggest gain in institutional ownership on average earn positive monthly abnormal returns post-listing. Six months after listing, the negative abnormal returns observed among firms in deciles seven through nine are not significant. Note that for each study period, an F-test rejects at a one-percent level the null hypothesis of equality of abnormal returns across the ten portfolios formed at the six-month and at the twelve-month post-listing period.

The results both for the pre- and post-listing periods shed more light on the institutional price-pressure hypothesis stated at the beginning of the paper. Institutional ownership changes unlike changes in overall ownership in listing firms, are positively associated with the abnormal return behavior of listing stock both before and after sample firms list on the NYSE. Specifically, firms in which an increase in institutional holdings occurs garner positive abnormal returns and vice versa both before and after they list on the NYSE.

\section{Conclusion}

Extant studies document that firms generally earn positive abnormal returns before listing and negative abnormal returns afterwards. This study empirically demonstrates that price-pressure by institutional owners may be responsible for the peculiar abnormal return behavior of stocks that list on the NYSE from the NASDAQ. Regression analyses reveal that both pre- and post-listing abnormal returns among listing firms are positively associated with the levels of institutional investor holdings in sample firms.

When listing firms are appropriately separated, those that experience erosion in institutional ownership exhibit negative abnormal returns and those exhibiting an increase in institutional holdings earn positive abnormal returns. This result is observed both before and after firms list on the NYSE. Our results are confirmed by designing portfolios based on deciles that reflect changes in the level of institutional owners in the listing firms. Over the 12month post listing period, firms that experience the largest increase (22 percent gain) in the level of institutional investors earn an average 0.76 percent abnormal returns over the same period. However, firms in deciles that experience the greatest erosion of institutional investors, (approximately a 14 percent drop) over the 12-month postlisting period earn an average of -3 percent abnormal returns over the that period.

Generally, whereas 'investor awareness' as suggested in Merton's (1987) model is supported by increases in the overall number of shareholders, sample firm abnormal returns around the listing event are mainly a function of changes in the levels of institutional ownership, suggesting institutional price-pressure. 
Table 5: Abnormal Returns For Initial Ownership Change In Ownership Stratified Portfolios.

To form the portfolios, firms are initially sorted into deciles based on their fraction of institutional ownership. Each decile is further stratified into deciles based on the change in the fraction of institutional ownership between the specified periods. Finally, I re-aggregate the deciles falling in the same rank in each initial ownership decile to obtain ten initial ownership changes in ownership-stratified portfolios. The average abnormal returns of the ten portfolios are reported below. An F-test conducted for the null hypotheses of the equality of the average abnormal returns across the deciles are rejected. T-statistics on the average values appear in brackets.

\begin{tabular}{|c|c|c|c|c|c|c|c|c|c|c|c|}
\hline & $\begin{array}{l}\text { Biggest } \\
\text { Loss }\end{array}$ & Decile 2 & Decile 3 & Decile 4 & Decile 5 & Decile 6 & Decile 7 & Decile 8 & Decile 9 & $\begin{array}{l}\text { Biggest } \\
\text { Gain }\end{array}$ & $\begin{array}{l}\text { F-Test } \\
\text { (p-value) }\end{array}$ \\
\hline $\begin{array}{l}\Delta \text { in the fraction of } \\
\text { Institutions }(\%) \\
(t=-12 \text { to } t=0)\end{array}$ & $\begin{array}{l}-0.1229 \\
(-14.05)^{* * *}\end{array}$ & $\begin{array}{l}-0.0643 \\
(-12.64) * * *\end{array}$ & $\begin{array}{l}0.0350 \\
(-11.81)^{* * *}\end{array}$ & $\begin{array}{l}-0.0121 \\
(-7.49) * * *\end{array}$ & $\begin{array}{l}0.0076 \\
(7.07)^{* * *}\end{array}$ & $\begin{array}{l}0.0284 \\
(23.02)^{* * *}\end{array}$ & $\begin{array}{l}0.0531 \\
(32.33)^{* * *}\end{array}$ & $\begin{array}{l}0.0895 \\
(34.85) * * *\end{array}$ & $\begin{array}{l}0.1466 \\
(30.85)^{* * *}\end{array}$ & $\begin{array}{l}0.3049 \\
(24.00)^{* * *}\end{array}$ & \\
\hline $\begin{array}{l}\text { Monthly Abnormal. } \\
\text { Return }(\%) \\
(t=-12 \text { to } t=0)\end{array}$ & $\begin{array}{l}-0.0093 \\
(-2.73)^{* * *}\end{array}$ & $\begin{array}{l}0.025 \\
(-0.73)\end{array}$ & $\begin{array}{l}-0.0027 \\
(-0.64)\end{array}$ & $\begin{array}{l}0.0017 \\
(0.47)\end{array}$ & $\begin{array}{l}-0.0007 \\
(-0.25)\end{array}$ & $\begin{array}{l}0.0005 \\
(1.85)^{*}\end{array}$ & $\begin{array}{l}0.0128 \\
(4.37)^{* * *}\end{array}$ & $\begin{array}{l}0.0114 \\
(2.42)^{* *}\end{array}$ & $\begin{array}{l}0.0137 \\
(3.91)^{* * *}\end{array}$ & $\begin{array}{l}0.0225 \\
(6.28)^{* * *}\end{array}$ & $\begin{array}{l}0.70 \\
(0.71)\end{array}$ \\
\hline $\begin{array}{l}\Delta \text { in the fraction of } \\
\text { Institutions }(\%) \\
(t=-6 \text { to } t=0)\end{array}$ & $\begin{array}{l}-0.1242 \\
(-13.16)^{* * *}\end{array}$ & $\begin{array}{l}-0.0683 \\
(-17.13)^{* * *}\end{array}$ & $\begin{array}{l}-0.0370 \\
(-15.28)\end{array}$ & $\begin{array}{l}-0.0198 \\
(-11.17)^{* * *}\end{array}$ & $\begin{array}{l}-0.0045 \\
(-3.32)^{* * *}\end{array}$ & $\begin{array}{l}0.0102 \\
(8.28)^{* * *}\end{array}$ & $\begin{array}{l}0.0294 \\
(22.45)^{* * *}\end{array}$ & $\begin{array}{l}0.0550 \\
(34.69) * * *\end{array}$ & $\begin{array}{l}0.0994 \\
(32.28)^{* * *}\end{array}$ & $\begin{array}{l}0.2318 \\
(22.21)^{* * *}\end{array}$ & \\
\hline $\begin{array}{l}\text { Monthly Abnormal } \\
\text { return }(\%) \\
(\mathrm{t}=-6 \text { to } \mathrm{t}=0)\end{array}$ & $\begin{array}{l}-0.0038 \\
(-0.59)\end{array}$ & $\begin{array}{l}-0.0037 \\
(-0.67)\end{array}$ & $\begin{array}{l}-0.0040 \\
(-0.83)\end{array}$ & $\begin{array}{l}0.0027 \\
(0.55)\end{array}$ & $\begin{array}{l}0.0089 \\
(2.35)^{* *}\end{array}$ & $\begin{array}{l}0.0065 \\
(1.53)\end{array}$ & $\begin{array}{l}0.0099 \\
(2.49)^{* * *}\end{array}$ & $\begin{array}{l}0.0122 \\
(1.57)\end{array}$ & $\begin{array}{l}0.0072 \\
(1.59)\end{array}$ & $\begin{array}{l}0.0213 \\
(4.55)^{* * *}\end{array}$ & $\begin{array}{l}2.15 \\
(0.02) * *\end{array}$ \\
\hline $\begin{array}{l}\Delta \text { in the fraction of } \\
\text { Institutions }(\%) \\
(\mathrm{t}=0 \text { to } \mathrm{t}=6)\end{array}$ & $\begin{array}{l}-0.1324 \\
(-11.66)^{* * *}\end{array}$ & $\begin{array}{l}-0.0652 \\
(-16.47)^{* * *}\end{array}$ & $\begin{array}{l}-0.0355 \\
(-15.61)^{* * *}\end{array}$ & $\begin{array}{l}-0.0160 \\
(-12.88)^{* * *}\end{array}$ & $\begin{array}{l}-0.0047 \\
(-6.11)^{* * *}\end{array}$ & $\begin{array}{l}0.0065 \\
(10.88)^{* * *}\end{array}$ & $\begin{array}{l}0.0215 \\
(30.36)^{* * *}\end{array}$ & $\begin{array}{l}0.0406 \\
(34.24)^{* * *}\end{array}$ & $\begin{array}{l}0.0706 \\
(38.37)^{* * *}\end{array}$ & $\begin{array}{l}0.1592 \\
(18.90)^{* * *}\end{array}$ & \\
\hline $\begin{array}{l}\text { Monthly Abnormal } \\
\text { return }(\%) \\
(\mathrm{t}=\mathbf{0} \text { to } \mathrm{t}=\mathbf{6})\end{array}$ & $\begin{array}{l}-0.0344 \\
(-4.30)^{* * *}\end{array}$ & $\begin{array}{l}-0.0282 \\
(-4.50)^{* * *}\end{array}$ & $\begin{array}{l}-0.0227 \\
(-2.96) * * *\end{array}$ & $\begin{array}{l}-0.0048 \\
(-0.93)\end{array}$ & $\begin{array}{l}-0.0144 \\
(-2.48) * *\end{array}$ & $\begin{array}{l}0.0049 \\
(0.94)\end{array}$ & $\begin{array}{l}-0.0018 \\
(-0.26)\end{array}$ & $\begin{array}{l}-0.0032 \\
(-0.65)\end{array}$ & $\begin{array}{l}-0.0023 \\
(-0.42)\end{array}$ & $\begin{array}{l}0.0104 \\
(2.06) * *\end{array}$ & $\begin{array}{l}3.07 \\
(0.00)^{* * *}\end{array}$ \\
\hline $\begin{array}{l}\Delta \text { in the fraction of } \\
\text { Institutions }(\%) \\
(\mathrm{t}=0 \text { to } \mathrm{t}=12)\end{array}$ & $\begin{array}{l}-0.1450 \\
(-10.95)^{* * *}\end{array}$ & $\begin{array}{l}-0.0728 \\
(-15.43) * * *\end{array}$ & $\begin{array}{l}-0.0456 \\
(-13.90) * * *\end{array}$ & $\begin{array}{l}-0.0202 \\
(-9.29)^{* * *}\end{array}$ & $\begin{array}{l}-0.0009 \\
(-0.80)\end{array}$ & $\begin{array}{l}0.0140 \\
(16.45)^{* *}\end{array}$ & $\begin{array}{l}0.0360 \\
(29.80)^{* * *}\end{array}$ & $\begin{array}{l}0.0609 \\
(38.44)^{* * *}\end{array}$ & $\begin{array}{l}0.1021 \\
(36.11)^{* * *}\end{array}$ & $\begin{array}{l}0.2268 \\
(23.81)^{* * *}\end{array}$ & \\
\hline $\begin{array}{l}\text { Monthly Abnormal } \\
\text { return }(\%) \\
(\mathrm{t}=0 \text { to } \mathrm{t}=12)\end{array}$ & $\begin{array}{l}-0.0302 \\
(-5.69)^{* * *}\end{array}$ & $\begin{array}{l}-0.0305 \\
(-6.60)^{* * *}\end{array}$ & $\begin{array}{l}-0.0183 \\
(-4.10)^{* * *}\end{array}$ & $\begin{array}{l}-0.0154 \\
(-3.98) * * *\end{array}$ & $\begin{array}{l}-0.0077 \\
(-2.17)^{* *}\end{array}$ & $\begin{array}{l}-0.0089 \\
(-2.48) * *\end{array}$ & $\begin{array}{l}-0.0098 \\
(-2.53)^{* *}\end{array}$ & $\begin{array}{l}-0.0100 \\
(-2.24) * *\end{array}$ & $\begin{array}{l}-0.0080 \\
(-2.24)^{* *}\end{array}$ & $\begin{array}{l}0.0076 \\
(2.09)^{* *}\end{array}$ & $\begin{array}{l}4.80 \\
(0.00)^{* * *}\end{array}$ \\
\hline $\begin{array}{ll}* * * & \text { Significant at } 1 \mathrm{p} \\
* * & \text { Significant at } 5 \mathrm{p} \\
* & \text { Significant at } 10\end{array}$ & $\begin{array}{l}\text { percent } \\
\text { percent } \\
\text { percent }\end{array}$ & & & & & & & & & & \\
\hline
\end{tabular}




\section{Suggestions For Future Research}

An obvious extension to this study would be to explore the price-pressure dynamics that lead international cross-listing securities to exhibit similar abnormal return behavior as reported here when they list on U.S. financial markets from foreign exchanges. Similar to US stock, the security price changes are transient. Extant work specifically Foerster and Karolyi (1999) relate the abnormal return dynamics to overall changes in investors in the spirit of the investor recognition hypothesis of Merton (1987). It would be interesting to explore and characterize the shareholder changes observed and relate them to share price changes of the listing stock in a manner that reveals the relationship between ownership and price-pressure. Needless to mention, such a study requires that other risk premia associated with listing from 'segmented' financial markets be controlled.

\section{Acknowledgements}

My thanks go first and foremost to my advisor Richard Sias the Gary P. Brinson Chair of Investment Management at Washington State University. I am grateful for the CDA Spectrum data support provided to Washington State through the Brinson Chair. I also thank the members of my committee: Harry Turtle and Halbert Kerr. I appreciate comments from John Nofsinger. Earlier versions of this paper have been presented at the Midwest Finance Meetings in Chicago (2000) and at the Financial Management Association and the Academy of Financial Services meetings in Toronto (2001). All remaining errors are my sole responsibility.

\section{Endnotes}

1. They define this as change in firms' predicted value caused by shocks from their VAR state variables that provide a "summary of information". The variables include profitability, book-to-market, and fraction of institutional ownership.

2. Section 13(f) of the 1934 act was added as a portion of the 1975 Securities Act Amendments. For a comprehensive discussion of the 13(f) data, refer to Lemke and Lins (1987).

3. The listing-month is intentionally left out since we seek to capture shifts in the anomalous returns between the pre- and the post-listing event windows. Further, we use listing months rather than announcement dates since the former approach is more appropriate for this study which overall, takes a fairly long-term rather than short-term analysis (see Karolyi and Foerster (1999)).

4. Over the period from PRE $=12$ to POST $=12$.

5. $\quad$ Over the period from PRE $=12$ to Post $=36$.

6. The number of shareholders is obtained from Standard and Poors' Research Insight. This average value may be computed from a slightly smaller number of observations than the number used for the rest of the average values.

7. Computed as Average Capitalization/Average Shares.

8. $\Delta \lambda_{\mathrm{j}}$ (numshar) is the predictor obtained with changes in the number of shareholders in (2) and $\Delta \lambda_{\mathrm{j}}$ (numinst) is the predictor obtained when we use changes in the number of institutional investors in the same equation. Refer to Kadlec and McConnell (1994) for an exposition on $\Delta \lambda_{j}$ (numshar).

9. Our initial concerns were that the regression may suffer from severe multicollinearity. From inspection, however, our R-squares are reasonably high and the standard errors on the estimates are small enough to yield significant coefficients. The two conditions suggest that multicollinearity is trivial ((2000) page 256).

10. The study period for the 12 month pre-listing abnormal returns is the event month $\mathrm{t}=-12$ until $\mathrm{t}=0$, and that for the six-month pre-listing period is from $t=6$ to $t=0$. The periods from $t=0$ to $t=6$, and $t=0$ to $t$ $=12$, are study periods for the six-month, and 12 -month, post-listing abnormal returns respectively.

11. Both the fraction of shares held by institutional investors and their number are coherent measures of institutional ownership (Parrino, Sias, and Starks (2003)). However, fractional institutional ownership may do better capturing changes in their ownership when that means they merely trim their holdings in sample firms as opposed to eliminating the ownership completely.

12. The portfolio aggregation method is similar to one used in Nofsinger and Sias (1999). 


\section{References}

1. Amihud, Yakov, Haim Mendelson, and Jun Uno, "Number of shareholders and stock prices: Evidence from Japan," The Journal of Finance, 54, pp. 1169-1184, 1999.

2. Asquith, P. and D. Mullins, "Equity issues and offering dilution," Journal of Financial Economics 15, pp. 61-89, 1986.

3. Baker, Kent H. John R. Nofsinger, and Daniel G. Weaver, "International cross listing and visibility," Journal of Financial and Quantitative Analysis, Vol. 37, No. 3, pp. 495-522, 2002.

4. Brown, C. Keith, and Bryce A. Brooke, "Institutional Demand and Security Price Pressure: The Case of Corporate Spin-offs," Financial Analysts Journal, Sep-Oct. pp. 53-62, 1993.

5. Cohen, Randolph B. Paul A. Gompers, Tuomo Vuolteenaho, "Who under reacts to cash flow news? Evidence from Trading between individuals and institutions," Journal of Financial Economics, 66, pp. 409-462, 2002.

6. Dharan, Bala G. and David Ikenberry, The long-run negative drift of post-listing stock returns. Journal of Finance 50, pp. 1547-1574, 1995.

7. Elliot, William B. and Richard Warr, "Price Pressure on the NYSE and NASDAQ: Evidence from S\&P 500 Index Changes," forthcoming Financial Management, 2003.

8. Foerster, Stephen R. and George. A. Karolyi, "The effects of market segmentation and Investor Recognition on asset prices: Evidence from foreign stocks listing in the U.S.," Journal of Finance, 54, pp. 981-1013, 1999.

9. Gillan, Stuart L. and Laura Starks, "Corporate governance proposals and shareholder activism: The role of institutional investor," Journal of Financial Economics, 57, pp. 275-305, 2000.

10. Gompers, Paul A. and Andrew Metric, "Institutional investors and equity prices, Quarterly Journal of Economics," 116, pp. 229-260, 2001.

11. Greene, H. William, Econometric Analysis, $4^{\text {th }}$ Edition, Prentice Hall, 2000.

12. Grinblatt, Mark, Sheridan Titman, and Russ Wermers, "Momentum investment strategies, portfolio performance, and herding: A study of mutual fund behavior," American Economic Review, 85, pp. 1088-1105, 1995.

13. Hudson, C. Marlin Jensen, and W. Pugh, "Informational versus Price pressure effects: Evidence from secondary offerings," The Journal of Financial Research, 16, 1, pp. 193-207, 1993.

14. Kadlec, Gregory B. and John J. McConnell, "The effect of market segmentation and illiquidity on asset prices: Evidence from exchange listings,” Journal of Finance, 49, pp. 611-636, 1994.

15. Karpoff, Jonathan M, Paul H. Malatesta, and Ralph A. Walkling, "Corporate governance and shareholder initiatives: Empirical evidence,” Journal of Financial Economics, 42, pp. 365-395, 1996.

16. Lakonishok, Josef, Andrei Shleifer, and Robert W. Vishny, "The impact of institutional trading on stock prices," Journal of Financial Economics 32, pp. 23-43, 1992.

17. Lemke, P. Thomas and Gerald T. Lins, The Business Lawyer, The American Bar Association, 1987.

18. Liang, Bing, "Price Pressure: Evidence from "Dartboard" Column," The Journal of Business, Vol. 72, 1, pp. 119-134, 1999.

19. Merton, Robert, "Presidential address: A simple model of capital market equilibrium with complete information," Journal of Finance, 42, pp. 483-510, 1987.

20. Miller P. Darius, "The market to international cross-listings: evidence from Depository Receipts, Journal of Financial Economics 51, pp. 103-123, 1999.

21. Nofsinger, John and Richard Sias, "Herding by institutional and individual investors," Journal of Finance, 54, pp. 2263-2294, 1999.

22. NYSE 2001 Fact Book, NYSE.

23. Parino, Robert, Richard W. Sias, and Laura Starks, "Voting with their Feet: Institutional Investors and CEO Turnover," Journal of Financial Economics, 68, 2003.

24. Pruitt, S. and K. Wei, "Institutional Ownership and Changes in the S\&P 500," Journal of Finance, 41, pp. 579-590, 1989.

25. Sanger, G. and J. McConnell, "Stock exchange listing, firm value and security market efficiency: The impact of the NASDAQ," Journal of Financial and Quantitative Analysis 21, pp. 1-25, 1986. 
26. Schwartz R. A., and Shapiro J.E., "The challenge of institutionalization for the equity market," In Saunders, A (Ed.), Recent developments in Finance, New York University Salomon Center, New York NY, 1992.

27. Wermers, Russ, "Mutual Fund Herding and the Impact on Stock Prices," Journal of Finance 54, pp. 581-622, 1999.

Notes 


\section{Do Not Print This Page!!}

\footnotetext{
${ }^{1}$ They define this as change in firms' predicted value caused by shocks from their VAR state variables that provide a "summary of information". The variables include profitability, book-to-market, and fraction of institutional ownership.

${ }^{2}$ Section 13(f) of the 1934 act was added as a portion of the 1975 Securities Act Amendments. For a comprehensive discussion of the 13(f) data, refer to Lemke and Lins (1987).

${ }^{3}$ The listing-month is intentionally left out since we seek to capture shifts in the anomalous returns between the preand the post-listing event windows. Further, we use listing months rather than announcement dates since the former approach is more appropriate for this study which overall, takes a fairly long-term rather than short-term analysis (see Karolyi and Foerster (1999)).

${ }^{4}$ Over the period from PRE $=12$ to POST $=12$.

${ }^{5}$ Over the period from PRE $=12$ to Post $=36$.

${ }^{6}$ The number of shareholders is obtained from Standard and Poors' Research Insight. This average value may be computed from a slightly smaller number of observations than the number used for the rest of the average values. ${ }^{7}$ Computed as Average Capitalization/Average Shares.

${ }^{88} \Delta \lambda_{\mathrm{j}}$ (numshar) is the predictor obtained with changes in the number of shareholders in (2) and $\Delta \lambda_{\mathrm{j}}$ (numinst) is the predictor obtained when we use changes in the number of institutional investors in the same equation. Refer to Kadlec and McConnell (1994) for an exposition on $\Delta \lambda_{j}$ (numshar).

${ }^{9}$ Our initial concerns were that the regression may suffer from severe multicollinearity. From inspection, however, our R-squares are reasonably high and the standard errors on the estimates are small enough to yield significant coefficients. The two conditions suggest that multicollinearity is trivial ((2000) page 256).

${ }^{10}$ The study period for the 12 month pre-listing abnormal returns is the event month $t=-12$ until $t=0$, and that for the six-month pre-listing period is from $t=6$ to $t=0$. The periods from $t=0$ to $t=6$, and $t=0$ to $t=12$, are study periods for the six-month, and 12-month, post-listing abnormal returns respectively.

${ }^{11}$ Both the fraction of shares held by institutional investors and their number are coherent measures of institutional ownership (Parrino, Sias, and Starks (2003)). However, fractional institutional ownership may do better capturing changes in their ownership when that means they merely trim their holdings in sample firms as opposed to eliminating the ownership completely.

${ }^{12}$ The portfolio aggregation method is similar to one used in Nofsinger and Sias (1999).
} 